\title{
Poverty, violence, and child protection
}

Any GP working in the UK in 2001 or since could not fail to be familiar with the name of Victoria Climbié. Aged 7, Victoria was brought from Cote d'Ivoire (Ivory Coast), West Africa to live with a great-aunt in London to fulfil her parents' hope of receiving a better education. In the most tragic of circumstances she died as a result of wilful neglect and abject cruelty at the hands of the aunt and her boyfriend, both subsequently sentenced to life imprisonment. A major inquiry followed her death. ${ }^{1}$ Lord Laming described the response of the health and social services who had been involved with this vulnerable child as 'lamentable' and his report catalogues the systematic failure of the many organisations involved with extensive recommendations for change.

Eight years later how much has changed since Victoria Climbié's potentially preventable death? Disturbingly, the situation has deteriorated. Homicide statistics for children in the UK show an annual increase with the highest number of 111 deaths recorded in 2007. ${ }^{2}$ The NSPCC gives rates of approximately 1-2 child deaths every week, carried out at the hands of parents or guardians. ${ }^{2}$

Why is this so? The government's rhetoric is unequivocal. Every Child Matters ${ }^{3}$ followed Laming's report and aimed to 'properly protect children at risk of neglect and harm within a framework of universal services, to prevent negative outcomes, and support every child to develop their full potential'. 'Children are precious' wrote Boateng in the introduction and are 'entitled to a strategy that safeguards them'.

The priority of child safety has remained on the agenda of government policy. In 2006 Working Together to Safeguard Children $^{4}$ was published and described the structure of Local Safeguarding Children's Boards to coordinate and to ensure the effectiveness of their member agencies in safeguarding and promoting the welfare of children, as underpinned by the Children's Act of 2004.
And yet our systems systematically fail vulnerable children and young people. As a GP I recently attended a mandatory child protection course and was horrified to hear of the stark realities which, in my view, would define how this county considers its youngest citizens. There can be few early childhood experiences which surpass the violation of trust and attachment wrought as a consequence of sexual abuse when perpetrated by a parent or guardian. Yet currently the disclosure rate for sexual abuse stands at around only 1 in 6 cases with $75 \%$ of children never disclosing abuse at the time. $^{5}$ Of those children who have sufficient resilience and support to pursue a judicial procedure the conviction rate is less than $5 \% .^{6}$

These horrific statistics of continuing and increasing child abuse have much to say about how we disregard children and their right to a happy childhood. The UK may have formally signed up to the United Nations Convention of the Rights of the Child (1989) but are these principles enshrined, not only in our policies but in our culture? The grim reality of many young people's lives would dispute this.

Sir Al Aynsley-Green, the UK's first Children's Commissioner, a former paediatrician and passionate advocate of children's rights has recently talked of a 'malaise' at the heart of British society. However, do current statistics of child abuse not suggest a more fundamental antipathy towards children and young people? As the UN Convention states, children have rights as human beings yet also need special care and protection. As their guardians, adults are responsible for the safe rearing of their young and yet we consistently let them down, as the statistics reveal. Where does this deep disregard for children stem from and how can it be addressed?

Fundamental to child abuse, whatever form it takes, is an abuse of power. Social scientists offer a number of theories to interpret the entrenchment of our disregard for children. Critical medical anthropology sees the root cause of violence in society as a pathology triggered by embedded inequality which lies at the heart of our class ridden society. Indeed social mobility has deteriorated and the gap between rich and poor widened over the last 30 years. ${ }^{7}$ Structural violence can be defined as 'the constraints on behaviour and options imposed by institutionalised inequalities in wealth and power on those who are underprivileged'. ${ }^{8}$ It is built on abuses of power which are most overt in countries with high rates of relative poverty.

Unequal societies foster unhappiness which can breed violence, of which child abuse is a key indicator. Britain has a poor track record with regard to disparities of income. The UK is currently ranked 21 st out of $27 \mathrm{EU}$ countries in terms of the proportion of people living in relative poverty $^{9}$ with some cities identified as having more than $50 \%$ of people considered as 'breadline poor', ${ }^{7}$ (Dorling et al define this condition as 'being excluded from participating in the norms of society'). ${ }^{7}$ Accepting that abuse can occur across the socioeconomic spectrum it is highest in areas of greater deprivation. Data pertaining to my practice area, Easington, the most deprived ward in the Trust, has four times as many children on the child protection register than Durham, the richest ward.

Addressing inequalities in society is complex. Systematic attempts to tackle disparities in income and the consequences on health are needed if we are to begin to address the root causes of violence in society. However, as doctors we can start now by being much more attentive to what young people have to say to us. Remaining alert to the possibility of child abuse is difficult to maintain over sustained periods of time without appropriate and clinically relevant reminders as part of continuing professional development. The RCGP has produced such an initiative in the form of a toolkit: Safeguarding Children and Young People in General Practice: A Toolkit. ${ }^{10}$ It is the result of a collaborative process between the College and the 
NSPCC and is for all those who wish to enhance their awareness and skills regarding child protection.

A group of young people working with the Children's Commission ${ }^{11}$ have recently identified 'violence, abuse, and bullying' as their number one problem and priority issue. This should not be a surprise to us, but will we as adults, entrusted with their care, hear what they are telling us? Unless we become more responsive to children and young people the rates of child abuse will remain unchanged and many childhoods damaged irreparably.

\section{Jane H Roberts}

\section{REFERENCES}

1. The Victoria Climbié Inquiry. Report of an inquiry by Lord Laming. Presented to Parliament in 2003. http://www.victoria-climbie-

inquiry.org.uk/finreport/finreport.htm (accessed 5 Aug 2008).

2. Creighton SJ, Tissier J. Child killings in England and Wales. London: NSPCC, 2006.

http://www.nspcc.org.uk/Inform/research/Briefings/ childkillingsinenglandandwales_wda48218.html (accessed 11 Aug 2008).

3. HM Government. Every child matters. London: The Stationery Office, 2003.

4. HM Government. Working together to safeguard children: a guide to inter-agency working to safeguard and promote the welfare of children. London: The Stationery Office, 2006.

5. Cawson, P, Wattam, C, Brooker, S, Kelly, G. Child maltreatment in the UK: a study of the prevalence of child abuse and neglect. London: 2000, NSPCC.

6. Home Office. Criminal statistics: England and Wales 2001. London: Stationery Office, 2002.

7. Dorling D, Rigby J, Wheeler B, et al. Poverty, wealth and place in Britain, 1968 to 2005. Bristol: Published for the Joseph Rowntree Foundation by The Policy Press, 2007.

8. Pool R, Geissler W. Medical anthropology. Open University Press: London, 2005.

9. Heath I. Let's get tough on the causes of inequality. BMJ 2007; 334: 1301.

10. Royal College of General Practitioners \& The National Society for the Prevention of Cruelty to Children. Safeguarding children and young people in general practice: A Toolkit. London: RCGP, 2007.http://www.rcgp.org.uk/PDF/CIR_Toolkit\%20d ocument $\% 20$ final\%20edit.pdf (accessed 5 Aug 2008)

11. The Children's Commission. 11 Million - The Children's commissioner for England. London: The Children's Commission, 2008.

http://www.11million.org.uk (accessed 5 Aug 2008).

\section{Good to see you back 007}

\section{DEVIL MAY CARE: SEBASTIAN FAULKS \\ Penguin, 2008}

HB, 320 pages, £18.99, 9780718153762

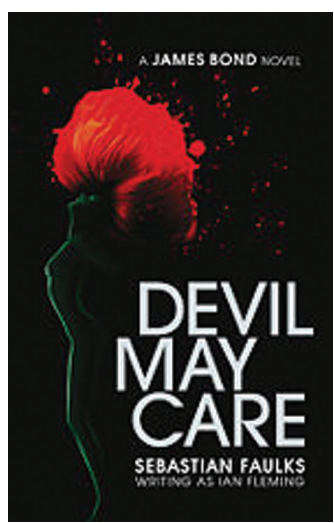

Sebastian Faulks is reported to have agreed to write Devil May Care over lunch and a fabulous Burgundy. Very Bond, who consumes heroic quantities of Dom Perignon, Stolichnaya, and Chateau Batailley, as well as martinis by the jugful. Most of the other Bond essentials are woven into this ripping yarn - the gorgeous girl who is not quite what she seems, the psychopathic baddie bent on world domination or destruction, the miraculous escapes from death and mutilation.

In the new Bond, however, the bad guys have nearly all the toys and James is notably underdressed, as well as underpowered (the Walther PPK is now regarded as a hairdresser's gun, the firearms equivalent of a BMW Z3). Q doesn't make an appearance, but $\mathrm{M}$ and Moneypenny are there, dependable as ever.

Faulks has set Devil May Care in the Middle East during the Cold War and captures both Fleming's journalist's prose style and the period milieu beautifully.

The disaffected lunatic at the centre of the plot disparages Britain's imperial adventures and at one point deprives Bond of food because of the Irish potato famine. The 100th anniversary of Fleming's birth (1908-1964) has generated a number of analyses of Bond's character - filling the void after a war which we won but come out secondbest, reconnecting with Empire - and there are elements of the Great Game between the British and the Russian Empire in Devil May Care, as well as telling echoes and parallels with present day concerns, including urban alienation, opiate addiction and the special relationship between Britain and the US.

Faulks' carefully structured plot and expert writing rarely falter, although there are a few Google moments where a plane or a car has been over-researched. There are some truly memorable scenes and terrific locations. Faulks also does a nice line in torture. The book gathers pace effortlessly and the last 100 pages are a real roller coaster. Great days.

\section{Roger Jones}

DOI: 10.3399/bjgp08X342093 